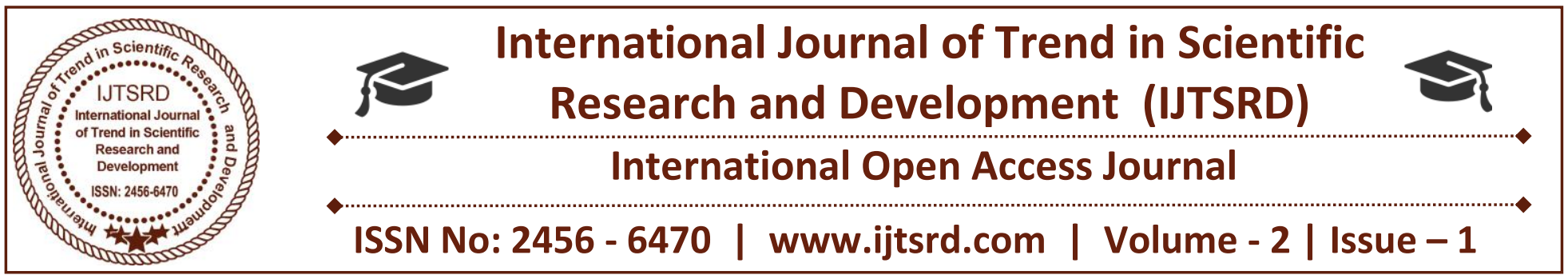

\title{
Empowering Skills of Indian Workforce through Training and Development
}

\author{
Arisha Siddiqui \\ Research Scholar, Dept. of Commerce, \\ A.M.U Aligarh, India
}

\author{
Sana Iqbal \\ Research Scholar, Dept. of Commerce, \\ A.M.U Aligarh, India
}

\section{ABSTRACT}

MAKE IN INDIA is a scheme of Indian Government for promoting international, as well as domestic, organizations to produce goods in India. It was created by Prime Minister Narendra Modi on 25 September 2014 with the motive to make India as a zenith place for FDI globally, leading China in addition to United States. MAKE IN INDIA is focusing on job creation, youth skilling, demand for skilled workforce in relation to skill development. Population of India is around 1.21 billion which is increasing rapidly at a rate of $17 \%$ undoubtedly India is one of the nations having workforce of the age group between 15-59 yrs, but unfortunately hardly $2 \%$ of this total workforce has gone through skills training .manpower of India is the most talented and hardworking one, therefore, India and can be a worldwide hub of skilled workforce through the programmes of training and development in upcoming time. Human resource is the most dynamic and versatile resource among all other resources like land, capital, money, machines etc. This is the only resource which needs to be upgraded from time to time so that they can make the best utilization of rest of the resources of an organization as well as of the nation too. Training and development is a tool or a technique to bridge the gap between upgraded skills of the workforce and need of the job. In today's scenario fast technological advancements taking place every here and now in the world. So, the Human resource is the backbone of any nation and to harness this resource through skill development should be the prime motive of every nation. This paper is an attempt to highlight the significance of skill development in the light of training and development as well as to highlight the govt. Initiatives in this regard, as the workforce is moving from agriculture to manufacturing and service sectors.

Keywords: training, development, skill development.

Training: Acc to Edwin B. Flippo, "Training is the act of increasing the knowledge and skill of an employee for doing a particular job."

Acc to Wayne f Cascio," Training consists of a planned program designed to improve performance at the individual, group and or organizational levels. Improved performance, in turn, implies that there have been measurable changes in knowledge, skills, attitudes and or social behavior."

Development: According to the American society of training and development (ASTD)," HRD is the integrated use of training and development, organizational development, and career development to improve individual, group, and organizational effectiveness."

Skill development: It is a process to enable an individual to gain an observable competency to perform a learned psychomotor act.

Objective: The objective of this paper is to emphasize the significance and need for skill development of Indian workforce. 
Methodology: This research paper is based on the secondary source of data obtained from websites of FICCI, planning commission report, report of National skill development policy, Wikipedia etc.

\section{Introduction:}

In this era of globalization and technological advancement, training and development is the only tool through which we can upgrade the skills of the human resource and prepare a skillful labor force for the tough, sustainable as well as fair escalation of the Nation. As per the report of FICCI" national skills policy in 2009 has put an objective of imparting skills training headed for 500 million near 2022.India is a land of abundant resources and human resource is that resource of this country, the skills and knowledge of which is the driving force of economic and social development. The workforce with high levels of skills and adaptability can cope up with the upcoming challenges and opportunities effectively and efficiently. As per the report of ILO" In Pittsburgh in September 2009, G20 leaders constructed a framework for strong, sustainable and balanced growth as a tool for their cooperative actions. They addressed and introduced the role of skill development in this regard stating that, "each of our countries will need through its own national policies to strengthen the ability of our workers to adapt to changing market demands and to benefit from innovation and investment in new technologies, clean energy, environment, health and infrastructure" .As India is one of the members of G20 so it will have to work in accordance with such framework too. Skill development makes the unskilled or semi-skilled workforce employable and raises the quality and dignity of labour. It prepares them for environmental, safety and health concerns through awareness programmes.

\section{Objectives of National skill development policy:}

1. To generate plus make available opportunities for everyone in the direction of learning skills all through their life, mainly in favour of youth, women as well as disadvantaged groups.

2. To encourage dedication among every stakeholder to be the owner of skill development initiatives.

3. To develop an elevated skilled workforce for current as well as upcoming employment market requirements.
4. To uphold efficient synchronization amid different ministries either central, state or public in addition to private providers.

\section{The scope of National skill development policy:}

1. Development of ITIS/ITCS/professional schools /technical schools/ polytechnics/ professional colleges etc. for skill development.

2. Spotlight on formal as well as informal apprenticeships along with additional categories of training via enterprises.

3. Provisions meant for self employment/entrepreneurial development.

4. Provisions designed for adult learning, retraining of retiring employees.

5. E-learning, web based learning as well as distance learning.

6. Sound as well as the well-organized execution of skill development programs.

An economy can raise only when it grows on an equitable basis so there should be skill development of all male/female/rural/urban/organized/unorganized employment and traditional contemporary workforce should be undertaken irrespective of all differences. Skill development systems should be so much efficient and effective which can smoothly connect education to technical training, training to labour market entry and labour market entry to the workplace and lifelong learning so that this can help the nation to gain sustainable productivity growth and transform such growth into more better jobs.

Skill development programs should aim to provide trained workers who can adjust dynamically to the challenging demands of employment and technologies.

The national skill development policy emphasized on the national vocational qualification framework which will provide a system whereby individuals get a platform to enhance their knowledge and skills so that they can convert them through testing and certification into higher diplomas and degrees.

It's a high time that govt. should calls for publicprivate partnership. More and more funds should be raised and used for all activities related to skill development programs than for building and other fixed assets. Therefore, up gradation of human resource, machinery and equipment, teaching and 
learning aids should be undertaken. For the enhancement of skill development programs the national skill development corporation is going to work with private skill development initiatives in order to give funding to the candidates rather than institutions. For e.g., scholarship, skill vouchers, outcome based reimbursement, etc. The course curriculum should be imparted with practical exposure through on the job training and apprenticeship. Govt. Is also taking initiatives to the assured quality of learning for which credible assessment and certifications are going to be developed. The mission statement, aims and objectives of the national skill development policy is "National skill development initiative will empower all individuals through improved skills and knowledge through national and international recognized qualifications to gain access to decent employment in order to ensure India's competitiveness in the global market."

Today the need of the hour is to develop such a skill set among the Indian workforce which can transform it into such a driving force who not only contribute to the growth of the economy but also to the sustainable growth of the nation.

Apart from other vocational skills, effort is undertaken to promote basic literacy, numeracy, occupational safety and health, hygiene, basic labour rights, teamwork and confidence building programme which will empower our weaker section of the nation too.

As India has set a target of skilling 500 million people by 2022 . So the nation is working with the joint efforts of government, public and private sectors to meet this challenge by:

- Establishing public training institutes in rural, border, hilly and difficult areas.

- Promoting mobile training, distance learning, elearning and web-based learning.

- Establishing skill development Centre's at village and block level.

- Promoting panchayats, municipalities and other local bodies to participate in skill development and creating employment at the local level with the help of SHG, cooperatives and NGOs.

- The country is making efforts to provide equal access to skill development for all social groups, like women and underprivileged section of society.

- For promoting skills and employability of women through skill development programs for construction, home-based traditional crafts or piece rate works, financial and health service as well as agricultural sectors.

- In order to raise the standard of living and employability of disadvantaged groups, scheduled castes , scheduled tribes, other backward classes .skill development programs are designed for benefitting these groups too.

- Minorities/persons with disabilities/school drops out and child labour, people living BPL etc. are promoted to take the advantages of national skill development programs for their upliftment so that they can secure quality life through enhancing their skills by short-term and vocational training courses.

Private sector with the support of govt. and other foreign agencies are making continuous efforts to enhance the scale of training programmes in India in order to make national human resource highly adaptable, capable and employable. Big players like Larsen and Turbo, Bharti group, Hero group, Maruti, ITC, infrastructure leasing and finance services ltd. etc. are promoting and providing world-class training facilities for giving a healthy and cooperative atmosphere of e-learning and innovation.

\section{Measures were taken by Govt. Of India:}

- Prime minister national skill development council.

- National skills development coordination board

- National skill development corporation board.

- National skill development agency.

- National skills policy.

- Apprenticeship act.

- Exchange ideas of skills training through international collaboration with developed countries like U.K, Germany, Australia etc.

- Memorandum of understanding (MOU) between Singapore's Institute of technical education and the state govt. Of new Delhi's dept.Of training and technical education.

- Rural development and self-employment training institutes (RUDSETI)

- National Council for vocational training (NCVT) 


\section{Why skill development:}

Due to change in demography of the country nearly $54 \%$ of the population under 25 yrs of age is having the ambition to get better jobs with higher incomes. The industrial growth and development calls for a workforce who is well trained and well equipped with all tools and techniques of doing quality work this is the only reason which has emphasized on the need of skill development programmes in the nation. As per the ministry of skill development and entrepreneurship "skill development develops a high degree of self-confidence, self-esteem and dignity that comes from education and knowledge, which enables them to stand on their own feet. Which gives wings to their ambitions so that they can convert their dreams into realities? No doubt skilling upgrades the personality of an individual as well as of the nation as a whole.

\section{Aims of skill development:}

1. Making efforts to improve the employability and ability of individuals to be adaptable to the altering technical as well as labors market weight.

2. Enhancing output as well as standard of livelihood of the populace.

3. Intensification competitiveness of nation.

4. Attracting investment deals for skillfulness .

Under skill development programmes we focus on two main skill set and these are:

\section{CORE SKILLS}

- SOCIAL

- COMMUNICATION

- PERSONAL

- BEHAVIOURAL

- ETHICAL

- LEARNING

- COGNITIVE/PROBLEM SLVING

VOCATIONAL /TECHNICAL SKILLS

\section{Parameters for Improving Quality:}

When we are talking about skill development through training and development programs it becomes imperative to assure its quality and relevance.

Following are some points in this regard:-

- In order to meet the standards of global economy, the quality of training should be raised to fulfil the requirement of the national and international market.

- For ensuring the quality of skill development programs candidates should be provided with the quality of infrastructure, quality of trainer and of course quality of education too.

- The establishment of national vocational qualification framework with the motive to promote nationally standardized and acceptable, international comparability of qualifications so all the bodies working for skill development follow the rules of this board.

- Well organized labour market for information system and human resource plan mechanisms help in matching the LMIS and HRP for promoting all time supply and demand in the labour market.

- Informal apprenticeships, fundamental education as well as soft skills, skill enlargement for selfemployment, provisions for lifelong learning etc. Should be a responsibility of all bodies working for skill development in India.

In spite of such a wide coverage of skill development in various sectors of the economy. There are still some sectors in which need of skill are very high but none of the ministries is taking any initiatives. Although training and development programs are conducted as per the need of market demand there is an absence of monitoring and planning at ministry level in such sectors. So work should be done on these parameters too.
- OCCUPATIONAL

- PROFESSIONAL

- ENTREPRENEURIAL

- COMPETENCE 
International Journal of Trend in Scientific Research and Development (IJTSRD) ISSN: 2456-6470

\section{SKILL DEVELOPMENT AND TRAINING PROGRAMMES UNDER VARIOUS MINISTRIES/ DEPARTMENTS}

\begin{tabular}{|c|c|c|c|c|}
\hline $\begin{array}{l}\text { Sl. } \\
\text { No. }\end{array}$ & $\begin{array}{l}\text { Ministry/ } \\
\text { Department }\end{array}$ & $\begin{array}{l}\text { Schemes/ Programmes/ } \\
\text { Institutions having provision } \\
\text { for Vocational Education } \\
\text { and } \\
\text { Training programme }\end{array}$ & Target Group & $\begin{array}{l}\text { Duration of } \\
\text { Training (long-term / } \\
\text { Short term) }\end{array}$ \\
\hline \multirow[t]{6}{*}{1.} & Agriculture & $\begin{array}{l}\text { Training in Agricultural } \\
\text { Extension (21 training } \\
\text { centres), } \\
\text { Training in use of Agricultural } \\
\text { Implements and machinery, } \\
\text { Soil } \\
\text { Conservation Training Centre, } \\
\text { LFQCandTI, NPPTI, } \\
\text { Cooperative } \\
\text { Education and Training. }\end{array}$ & $\begin{array}{l}\text { Person engaged in } \\
\text { Agricultural institutions } \\
\text { and support services, } \\
\text { members of cooperatives } \\
\text { and Farmers. Under KVK, } \\
550 / 589 \text { districts are } \\
\text { covered. }\end{array}$ & $\begin{array}{l}\text { Short term } \\
\text { courses }\end{array}$ \\
\hline & & $\begin{array}{l}\text { Under the University stream, } \\
\text { various undergraduate, } \\
\text { postgraduate and PhD courses } \\
\text { are offered (DARE). }\end{array}$ & $\begin{array}{l}\text { Students with } \\
\text { Qualifications as usual } \\
\text { under University stream of } \\
\text { education. }\end{array}$ & $\begin{array}{l}\text { U.G. courses }-4 \\
\text { years, P.G. Courses }-2 \\
\text { years and } \mathrm{PhD} \text { as usual. }\end{array}$ \\
\hline & & $\begin{array}{l}\text { There is one Central } \\
\text { Agricultural University, thirty- } \\
\text { one State Agricultural } \\
\text { Universities (SAUs) and four } \\
\text { National Institutes of Indian } \\
\text { Council of Agricultural } \\
\text { Research having the status of } \\
\text { Deemed University. }\end{array}$ & $\begin{array}{l}\text { Students with } \\
\text { Qualifications as usual. }\end{array}$ & As usual. \\
\hline & & $\begin{array}{l}\text { ICAR also arranges need based } \\
\text { training programmes in any of } \\
\text { State Agricultural University } \\
\text { or ICAR Institutes in new and } \\
\text { emerging areas. }\end{array}$ & $\begin{array}{l}\text { Individual scientists or } \\
\text { groups of scientists. }\end{array}$ & $\begin{array}{l}\text { One week to } \\
\text { three months (or } \\
\text { longer duration, } \\
\text { as fixed). }\end{array}$ \\
\hline & & $\begin{array}{l}\text { CIFNET }- \text { Regular courses } \\
\text { and special training courses }\end{array}$ & 10th Standard students & $6-18$ months \\
\hline & & CIFNET - Refresher courses & Lecturers/in-service & 4 weeks \\
\hline \multirow[t]{4}{*}{2.} & $\begin{array}{l}\text { Food } \\
\text { Processing } \\
\text { Industries }\end{array}$ & $\begin{array}{l}\text { Grants were provided to NGOs } \\
\text { for setting up of } 326 \text { Food } \\
\text { Processing and Training } \\
\text { Centres }\end{array}$ & $\begin{array}{l}\text { Persons living in rural } \\
\text { areas with preference } \\
\text { being given to women, }\end{array}$ & \\
\hline & & $\begin{array}{l}\text { (FPTCs) during 1992-93 to } \\
2000-01 \text {. }\end{array}$ & $\begin{array}{l}\text { SC, ST and other weaker } \\
\text { sections of society }\end{array}$ & \\
\hline & & $\begin{array}{l}\text { Institutions like Central Food } \\
\text { Technology Research Institute, } \\
\text { Paddy Processing Research } \\
\text { Centre, PHTC, Council of } \\
\text { Entrepreneurial Development } \\
\text { Programme (EDP) are also } \\
\text { running training courses. }\end{array}$ & $\begin{array}{l}\text { Mainly persons in Food } \\
\text { Processing Industry }\end{array}$ & Short term \\
\hline & & Person power development in & Open & Short term \\
\hline
\end{tabular}


International Journal of Trend in Scientific Research and Development (IJTSRD) ISSN: 2456-6470

\begin{tabular}{|c|c|c|c|c|}
\hline & & rural areas (FBTC Scheme) & & \\
\hline & & $\begin{array}{l}\text { Entrepreneurship Development } \\
\text { Programme }\end{array}$ & Open & Short term \\
\hline & & $\begin{array}{l}\text { Programmes for development } \\
\text { of human resources in food } \\
\text { processing, testing, training, } \\
\text { quality management etc. }\end{array}$ & $\begin{array}{l}\text { Candidates aspiring to be } \\
\text { Managers, technician/ } \\
\text { technologists, and } \\
\text { entrepreneurs }\end{array}$ & $\begin{array}{l}\text { AICTE approved } \\
\text { diploma/degree } \\
\text { courses "durations as } \\
\text { usual (Longterm) }\end{array}$ \\
\hline $\begin{array}{l}\text { Sl. } \\
\text { No. }\end{array}$ & $\begin{array}{l}\text { Ministry/ } \\
\text { Department }\end{array}$ & $\begin{array}{l}\text { Schemes/ Programmes/ } \\
\text { Institutions having provision } \\
\text { for Vocational Education } \\
\text { and } \\
\text { Training programme }\end{array}$ & Target Group & $\begin{array}{l}\text { Duration of } \\
\text { Training (long-term / } \\
\text { Short term) }\end{array}$ \\
\hline \multirow[t]{2}{*}{3.} & $\begin{array}{l}\text { Health and } \\
\text { Family } \\
\text { Welfare }\end{array}$ & $\begin{array}{l}\text { Basic Training of multipurpose } \\
\text { a health worker (Female and } \\
\text { Male) } \\
\bullet \quad 478 \text { ANM/MPW(F) } \\
\text { Training Centres } \\
\qquad \quad 28 \text { HFWTC and } 30 \\
\quad \text { Basic } \\
M P W A(M) \text { Schools }\end{array}$ & $\begin{array}{l}\text {-Educated youth with } \\
\text { minimum 10th pass }\end{array}$ & 12 to 18 months \\
\hline & & $\begin{array}{l}\text { Promotional training for } \\
\text { Female Health Assistant in } 42 \\
\text { training centres. Training is } \\
\text { also provided by Safdarjung } \\
\text { Hospital, } \\
\text { NTCP, NPCB, NMHP, NACP, } \\
\text { INC, CBHI, CLTRI, PWTRC, } \\
\text { ECH etc. }\end{array}$ & $\begin{array}{l}\text {-Persons working in } \\
\text { Health and family } \\
\text { Welfare programme }\end{array}$ & Short term \\
\hline 4. & $\begin{array}{l}\text { Heavy } \\
\text { Industries and } \\
\text { Public } \\
\text { Enterprises }\end{array}$ & $\begin{array}{l}\text { Counselling, Retraining and } \\
\text { Redeployment of rationalized } \\
\text { Workers of CPSEs (Formerly } \\
\text { NRF) }\end{array}$ & $\begin{array}{l}\text { Workers who opt for } \\
\text { voluntary retirement, } \\
\text { rendered surplus or } \\
\text { retrenched from CPSEs }\end{array}$ & $\begin{array}{l}\text { Short term } \\
\text { courses }\end{array}$ \\
\hline \multirow[t]{5}{*}{5.} & $\begin{array}{l}\text { Human } \\
\text { Resource } \\
\text { Development }\end{array}$ & $\begin{array}{lr}\text { Vocationalisation } & \text { of } \\
\text { Secondary Education } & (6800 \\
\text { schools covered }) & \end{array}$ & $\begin{array}{l}\text { Student having passed } \\
\text { 10th } \\
\text { Class }\end{array}$ & 2 years \\
\hline & & $\begin{array}{l}\text { Polytechnics (1244) + } \\
\text { Institutions for diploma in } \\
\text { pharmacy (415), hotel } \\
\text { management (63), architecture } \\
(25)\end{array}$ & 10th pass & 3 years diploma \\
\hline & & $\begin{array}{l}\text { Community Polytechnic } \\
\text { Scheme (675 CPs) }\end{array}$ & $\begin{array}{l}\text { Poorer sections of society } \\
\text { in both rural and urban } \\
\text { areas }\end{array}$ & (3 to 6 months) \\
\hline & & $\begin{array}{l}\text { Jan Shikshan Sansthan } \\
\text { ( } 157 \text { Vocational Training } \\
\text { Centres run by NGOs offering } \\
\text { more than } 250 \text { courses) }\end{array}$ & $\begin{array}{l}\text { Disadvantaged groups of } \\
\text { adults. Priority is given to } \\
\text { adult neo-literates/ } \\
\text { semiliterates, SC and ST, } \\
\text { women/girls, oppressed, } \\
\text { migrants, slum/ pavement } \\
\text { dwellers and working } \\
\text { children }\end{array}$ & $\begin{array}{l}\text { Need-Based } \\
(1-4 \text { weeks })\end{array}$ \\
\hline & & Support For Distance & Engineering and physical & (Designing \\
\hline
\end{tabular}


International Journal of Trend in Scientific Research and Development (IJTSRD) ISSN: 2456-6470

\begin{tabular}{|c|c|c|c|c|}
\hline & & $\begin{array}{l}\text { Education and Web Based } \\
\text { Learning (NPTEL) }\end{array}$ & $\begin{array}{l}\text { sciences undergraduates/ } \\
\text { postgraduates in the } \\
\text { country; all teachers/ } \\
\text { faculties in science and } \\
\text { engineering Universities in } \\
\text { India }\end{array}$ & $\begin{array}{l}\text { course material - } \\
\text { time bound } \\
\text { project) }\end{array}$ \\
\hline & & $\begin{array}{l}\text { National Institute of Open } \\
\text { Schooling -Distance } \\
\text { Vocational } \\
\text { Programmes [Practical training } \\
\text { through Accredited Vocational } \\
\text { Institutes (AVIs)] }\end{array}$ & $\begin{array}{l}\text { School leavers with 5th, } \\
7 \text { th, 8th and 10th pass }\end{array}$ & 6 months to 2 years \\
\hline & & $\begin{array}{l}\text { Apprenticeship Training for } \\
\text { student of }+2 \text { Vocational } \\
\text { stream }\end{array}$ & $\begin{array}{l}\text { Students passing out of }+2 \\
\text { Vocational stream }\end{array}$ & One year \\
\hline \multirow[t]{2}{*}{$\begin{array}{l}\text { Sl. } \\
\text { No. }\end{array}$} & $\begin{array}{l}\text { Ministry/ } \\
\text { Department }\end{array}$ & $\begin{array}{l}\text { Schemes/ Programmes/ } \\
\text { Institutions having provision } \\
\text { for Vocational Education } \\
\text { and } \\
\text { Training programme }\end{array}$ & Target Group & $\begin{array}{l}\text { Duration of } \\
\text { Training (long-term / } \\
\text { Short term) }\end{array}$ \\
\hline & & $\begin{array}{l}\text { National Programme on } \\
\text { Earthquake Engineering } \\
\text { Education (NPEEE) }\end{array}$ & $\begin{array}{l}\text { Recognized engineering } \\
\text { colleges/ polytechnics and } \\
\text { schools of architecture } \\
\text { having related academic } \\
\text { degree or diploma } \\
\text { programme }\end{array}$ & $\begin{array}{l}\text { Faculty } \\
\text { development } \\
\text { through short-term } \\
\text { crash } \\
\text { programmes and } \\
\text { long-term } \\
\text { programmes }\end{array}$ \\
\hline \multirow[t]{2}{*}{6.} & $\begin{array}{l}\text { Information } \\
\text { Technology }\end{array}$ & DOEACC - „,O $\mathrm{O}^{e e}$ level & $\begin{array}{l}\text { Students or working } \\
\text { persons with } 10+2 \text { pass }\end{array}$ & $\begin{array}{l}\text { Flexible duration } \\
\text { for passing } \\
\text { examination }\end{array}$ \\
\hline & & CEDTI & $\begin{array}{l}\text { It conducts courses in the } \\
\text { field of Electronics, } \\
\text { Telecommunications, IT, } \\
\text { Process Control and } \\
\text { Instrumentation }\end{array}$ & $\begin{array}{l}\text { Short term } \\
\text { courses }\end{array}$ \\
\hline \multirow[t]{6}{*}{7.} & $\begin{array}{l}\text { Labour and } \\
\text { Employment } \\
(\text { DGET })\end{array}$ & $\begin{array}{l}\text { Craftsmen Training Scheme } \\
\text { (CTS) } \\
\text { (6834 ITI/ITCs) }\end{array}$ & $\begin{array}{l}\text { School leavers with } 8 \text { th, } \\
10 \text { th and 12th pass }\end{array}$ & $\begin{array}{l}\text { Six months to } \\
\text { Three years }\end{array}$ \\
\hline & & $\begin{array}{l}\text { Apprenticeship Training } \\
\text { Scheme (ATS) } \\
(23,800 \text { establishments) }\end{array}$ & $\begin{array}{l}\text { School leavers with 8th, } \\
\text { 10th and 12th pass or } \\
\text { National Trade Certificate } \\
\text { Holder }\end{array}$ & $\begin{array}{l}\text { Six months to } 4 \\
\text { years }\end{array}$ \\
\hline & & $\begin{array}{l}\text { Modular Employable } \\
\text { Skills(MES) }\end{array}$ & $\begin{array}{lr}\text { School dropouts } & \text { and } \\
\text { unorganized } & \text { sector } \\
\text { workers } & \end{array}$ & $\begin{array}{l}\text { Short term (60 hrs to } \\
1000 \mathrm{hrs})\end{array}$ \\
\hline & & $\begin{array}{l}\text { Crafts Instructor Training } \\
\text { Scheme (CITS) (6 Institutes) }\end{array}$ & Instructors of ITIs/ITCs & 1 year \\
\hline & & $\begin{array}{l}\text { Advanced Vocational Training } \\
\text { Scheme and Hi-tech Training } \\
\text { Scheme ( } 65 \text { centres })\end{array}$ & $\begin{array}{l}\text { Industrial Workers/ } \\
\text { Technicians }\end{array}$ & $\begin{array}{l}\text { Short Term } \\
\text { courses }\end{array}$ \\
\hline & & Supervisory Training (2 & Supervisors from Industry & Long and short \\
\hline
\end{tabular}


International Journal of Trend in Scientific Research and Development (IJTSRD) ISSN: 2456-6470

\begin{tabular}{|c|c|c|c|c|}
\hline & & institutes) & & term \\
\hline & & $\begin{array}{l}\text { Women Training Institutes(11 } \\
\text { institutes) }\end{array}$ & $\begin{array}{l}\text { Women (School leavers, } \\
\text { Instructors and others) }\end{array}$ & $\begin{array}{l}\text { Long and short } \\
\text { term }\end{array}$ \\
\hline & & $\begin{array}{l}\text { Central Staff Training and } \\
\text { Research Institute }\end{array}$ & $\begin{array}{l}\text { Training Executives and } \\
\text { Principals }\end{array}$ & Short Term \\
\hline & & $\begin{array}{l}\text { Model Training Institutes and } \\
\text { Model Industrial Training } \\
\text { Institutes. }\end{array}$ & $\begin{array}{l}\text { School leavers with 8th, } \\
\text { 10th and 12th pass }\end{array}$ & $\begin{array}{l}\text { One to Three } \\
\text { years }\end{array}$ \\
\hline \multirow[t]{2}{*}{8.} & $\begin{array}{l}\text { Rural } \\
\text { Development }\end{array}$ & $\begin{array}{lrr}\text { National Institute of Rural } \\
\begin{array}{l}\text { Development } \\
\text { Conducts }\end{array} & \text { about } & 150 \\
\text { programmes } & & \end{array}$ & $\begin{array}{l}\text { Practicising Manager in } \\
\text { rural development }\end{array}$ & $\begin{array}{l}\text { Short term } \\
\text { Courses }\end{array}$ \\
\hline & & $\begin{array}{l}\text { Swarnjayanti Gram Swarozgar } \\
\text { Yojana (SGSY) }\end{array}$ & $\begin{array}{l}\text { Focus is on the vulnerable } \\
\text { groups among the rural } \\
\text { poor. SC/ STs would } \\
\text { account for a minimum of } \\
50 \% \text {, women for } 20 \% \text { and } \\
\text { disabled for } 3 \% \text { of the total } \\
\text { swarozgaris during a } \\
\text { year. }\end{array}$ & $\begin{array}{l}\text { Need-based short } \\
\text { term }\end{array}$ \\
\hline \multirow[t]{2}{*}{$\begin{array}{l}\text { Sl. } \\
\text { No. }\end{array}$} & $\begin{array}{l}\text { Ministry/ } \\
\text { Department }\end{array}$ & $\begin{array}{l}\text { Schemes/ Programmes/ } \\
\text { Institutions having provision } \\
\text { for Vocational Education } \\
\text { and } \\
\text { Training programme }\end{array}$ & Target Group & $\begin{array}{l}\text { Duration of } \\
\text { Training (long-term / } \\
\text { Short term) }\end{array}$ \\
\hline & & $\begin{array}{l}\text { RUDSETIS train about } 1.25 \\
\text { Lakh per annum Skill } \\
\text { development of BPL } \\
@ 50000 \text { per annum }\end{array}$ & & Short term \\
\hline 9. & $\begin{array}{l}\text { MSME } \\
\text { [Small } \\
\text { Industries } \\
\text { Development } \\
\text { Organisation } \\
\text { (SIDO)] }\end{array}$ & $\begin{array}{l}\text { Entrepreneurship Development } \\
\text { Programme, } \\
\text { Development } \\
\text { Programme (SDP), } \\
\text { Management Development } \\
\text { Programme } \\
\quad \text { O It has } 72 \text { institutes/ } \\
\quad \text { bodies. } \\
\text { - SSSI-30 } \\
\text { - Br. SSSI- } 28 \\
\text { - } R T C-4 \\
\text { - Tool Rooms }-8 \\
\text { - PPDC - } 2\end{array}$ & $\begin{aligned} \text { - } & \text { Workers } \\
\text { - } & \text { Educated } \\
& \text { unemployed } \\
\text { youth } & \\
\text { - } & \text { Entrepreneurs }\end{aligned}$ & $\begin{array}{l}\text { Both short-term } \\
\text { and long-term }\end{array}$ \\
\hline 10. & $\begin{array}{l}\text { Khadi and } \\
\text { Village } \\
\text { Industries } \\
\text { Commission } \\
\text { under } \\
\text { Ministry } \\
\text { of MSME }\end{array}$ & $\begin{array}{l}51 \text { Training Centres run } 35 \\
\text { types of programmes }\end{array}$ & $\begin{array}{l}\text { Unemployed rural youth, } \\
\text { In-job } \\
\text { Artisans/Supervisors } \\
\text { working in KVI instts, } \\
\text { Prospective Entrepreneurs, } \\
\text { Beneficiaries of different } \\
\text { Government. Schemes } \\
\text { desirous of undertaking } \\
\text { KVI activities. }\end{array}$ & $\begin{array}{l}2 \text { months to } 12 \\
\text { months }\end{array}$ \\
\hline
\end{tabular}


International Journal of Trend in Scientific Research and Development (IJTSRD) ISSN: 2456-6470

\begin{tabular}{|c|c|c|c|c|}
\hline 11. & $\begin{array}{l}\text { Social Justice } \\
\text { and } \\
\text { Empowerment }\end{array}$ & $\begin{array}{l}\text { National Institute of Mentally } \\
\text { Handicapped, National } \\
\text { Institute for the Orthopedically } \\
\text { Handicapped, Institute for } \\
\text { Physically Handicapped, } \\
\text { National Institute for the } \\
\text { Hearing Handicapped, } \\
\text { National Handicapped Finance } \\
\text { and Development Corporation, } \\
\text { National Scheme of Liberation } \\
\text { and Rehabilitation of } \\
\text { Scavengers and their } \\
\text { Dependents, National } \\
\text { Scheduled Castes and } \\
\text { Scheduled Tribes Finance and } \\
\text { Development Corporation, } \\
\text { Rehabilitation Council of India }\end{array}$ & $\begin{array}{l}\text { Disadvantaged and } \\
\text { marginalized sections of } \\
\text { the society viz., SC, } \\
\text { Minorities, B.C., Persons } \\
\text { with disabilities, Aged } \\
\text { Persons, Street children } \\
\text { and victims of Drug } \\
\text { Abuse etc. }\end{array}$ & $\begin{array}{l}\quad>\text { Short term } \\
\text { training upto } \\
\text { six months } \\
\text { duration } \\
\text { Orientation } \\
\text { Programmes } \\
\text { upto one week duration } \\
\text { (15 days to } 3 \text { months). } \\
\\
\text { Some courses } \\
\text { under } \\
\text { Handicrafts } \\
\text { are of } 1 \text { year } \\
\text { duration. }\end{array}$ \\
\hline 12. & Textiles & $\begin{array}{l}\text { Decentralized } \\
\text { TrainingProgramme, } 24 \\
\text { Weavers "Service Centres, } \\
\text { Cooperative Training, } 13 \\
\text { Power loom Centres, Indian } \\
\text { Jute Industries Research } \\
\text { Association, Central Wool } \\
\text { Development Board, Central } \\
\text { Silk Board, Training Centres } \\
\text { for Handicrafts, Northeastern } \\
\text { Handicrafts and handlooms } \\
\text { development } \\
\text { Corporation }\end{array}$ & $\begin{array}{l}\text { Skill upgradation of } \\
\text { Workers in textile } \\
\text { Industry }\end{array}$ & $\begin{array}{l}\quad>\text { Mainly short } \\
\text { term (15 days } \\
\text { to } 3 \text { months). } \\
\qquad>\text { Some courses } \\
\text { under } \\
\text { Handicrafts of } 1 \text { year } \\
\text { duration. }\end{array}$ \\
\hline $\begin{array}{l}\text { Sl. } \\
\text { No. }\end{array}$ & $\begin{array}{l}\text { Ministry/ } \\
\text { Department }\end{array}$ & $\begin{array}{l}\text { Schemes/ Programmes/ } \\
\text { Institutions having provision } \\
\text { for Vocational Education } \\
\text { and } \\
\text { Training programme }\end{array}$ & Target Group & $\begin{array}{l}\text { Duration of } \\
\text { Training (long-term / } \\
\text { Short term) }\end{array}$ \\
\hline & & $\begin{array}{l}\text { Apparel Export Promotion } \\
\text { Council (AEPC) }\end{array}$ & $\begin{array}{l}\text { Workers in Garment } \\
\text { Industry }\end{array}$ & $\begin{array}{l}3 \text { months to } 1 \\
\text { year }\end{array}$ \\
\hline 13. & Tourism & $\begin{array}{l}15 \text { Food Craft Institutes under } \\
\text { State Governments }\end{array}$ & 10th Pass & $\begin{array}{l}6 \text { months }-1 \\
\text { year }\end{array}$ \\
\hline 14. & Tribal Affairs & $\begin{array}{l}\text { Vocational Training Centres } \\
\text { (VTC) in Tribal Areas. } \\
\text { (100\% central assistance is } \\
\text { given to State/ UT / NGO for } \\
\text { setting up VTs. }\end{array}$ & $\begin{array}{l}\text { Unemployed Tribal youth } \\
\text { (Each person is given } \\
\text { training in two trades) }\end{array}$ & $\begin{array}{l}6 \text { months in VTC } \\
\text { and } 6 \text { months } \\
\text { with master } \\
\text { craftsmen }\end{array}$ \\
\hline 15. & $\begin{array}{l}\text { Urban } \\
\text { Development } \\
\text { and Poverty } \\
\text { alleviation }\end{array}$ & $\begin{array}{l}\text { Urban Self Employment } \\
\text { Programme under Swarna } \\
\text { Jayanti Shahari Rozgar Yojana } \\
\text { (SJSRY) }\end{array}$ & $\begin{array}{l}\text { Urban Unemployed or } \\
\text { underemployed poor } \\
\text { below the poverty line }\end{array}$ & $\begin{array}{l}\text { Short term } \\
\text { (2-6 months) } \\
\text { subject to } \\
\text { minimum } 300 \\
\text { hours }\end{array}$ \\
\hline 16. & $\begin{array}{l}\text { HUDCO and } \\
\text { others in }\end{array}$ & $\begin{array}{l}640 \text { Building Centres } \\
\text { (HUDCO) }\end{array}$ & $\begin{array}{l}\text { Persons engaged in } \\
\text { Construction Industry }\end{array}$ & $\begin{array}{l}\text { Short term } \\
\text { courses }\end{array}$ \\
\hline
\end{tabular}


International Journal of Trend in Scientific Research and Development (IJTSRD) ISSN: 2456-6470

\begin{tabular}{|c|c|c|c|c|}
\hline & $\begin{array}{l}\text { Construction } \\
\text { sector under } \\
\text { Ministry of } \\
\text { Urban } \\
\text { Development } \\
\text { and Planning } \\
\text { Commission }\end{array}$ & $\begin{array}{l}\text { Company run schools (NBCC } \\
\text { HCC, LandT, ECC etc.) and } \\
\text { association etc. } \\
\text { Construction Industry } \\
\text { Development Council (CIDC) } \\
\text { and others }\end{array}$ & & $\begin{array}{l}\text { Short term } \\
\text { courses } \\
1 \text { month to } \\
6 \text { months }\end{array}$ \\
\hline \multirow[t]{4}{*}{17.} & $\begin{array}{l}\text { Women and } \\
\text { Child } \\
\text { Development }\end{array}$ & $\begin{array}{l}\text { Support to Training and } \\
\text { Employment Programme for } \\
\text { Women (STEP) }\end{array}$ & $\begin{array}{l}\text { To provide updated skills } \\
\text { and new knowledge to } \\
\text { poor and assetless women } \\
\text { traditional sectors }\end{array}$ & $\begin{array}{l}\text { Short term } \\
\text { courses }\end{array}$ \\
\hline & & $\begin{array}{l}\text { Swalamban (previously } \\
\text { NORAD) }\end{array}$ & $\begin{array}{l}\text { To train poor women } \\
\text { mostly in non-traditional } \\
\text { trades }\end{array}$ & \\
\hline & & $\begin{array}{l}\text { Training in home scale } \\
\text { preservation of fruits and } \\
\text { vegetables, (by Community } \\
\text { Food and Nutrition Extension } \\
\text { Units (CFNEUs) }\end{array}$ & $\begin{array}{l}\text { Housewives and } \\
\text { adolescent girls with a } \\
\text { view to promote } \\
\text { preservation and } \\
\text { consumption of fruits and } \\
\text { vegetables which provide } \\
\text { much needed } \\
\text { micronutrients, as well as } \\
\text { to provide necessary skills } \\
\text { which could be used for } \\
\text { income generation } \\
\text { purposes. }\end{array}$ & Two weeks \\
\hline & & $\begin{array}{l}\text { Central Social Welfare Board } \\
\text { (programmes are organised by } \\
\text { voluntary organisations) }\end{array}$ & $\begin{array}{l}\text { To train women in } \\
\text { marketable trades and also } \\
\text { to upgrade their skills for } \\
\text { getting remunerative } \\
\text { employment opportunities }\end{array}$ & \\
\hline \multirow[t]{3}{*}{$\begin{array}{l}\text { Sl. } \\
\text { No. }\end{array}$} & $\begin{array}{l}\text { Ministry/ } \\
\text { Department }\end{array}$ & $\begin{array}{l}\text { Schemes/ Programmes/ } \\
\text { Institutions having provision } \\
\text { for Vocational Education } \\
\text { and } \\
\text { Training programme }\end{array}$ & Target Group & $\begin{array}{l}\text { Duration of } \\
\text { Training (long-term / } \\
\text { Short term) }\end{array}$ \\
\hline & & $\begin{array}{l}\text { Women Empowerment } \\
\text { Programme in collaboration } \\
\text { with IGNOU (Training } \\
\text { programme on "Empowering } \\
\text { women through SHG") } \\
\text { Kishori Shakti Yojana }\end{array}$ & $\begin{array}{l}\text { To organise women into } \\
\text { effective Self Help Groups }\end{array}$ & \\
\hline & & Kishori Shakti Yojana & $\begin{array}{l}\text { To train and equip } \\
\text { adolescent girls to } \\
\text { improve home-based and } \\
\text { vocational skills }\end{array}$ & \\
\hline
\end{tabular}




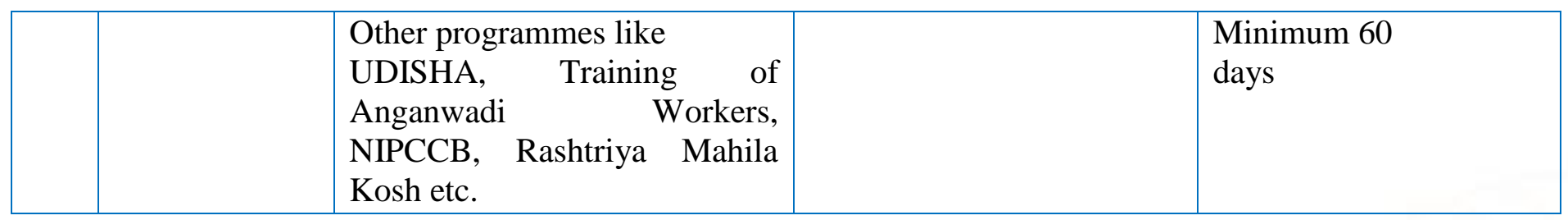

\section{Source: FICCI-Ernst \& Young: Knowledge Paper on 'Strategic and Implementation Framework for Skill Development in India. September 2011}

\section{CONCLUSION:}

Prime Minister Narendra Modi has formulated revised National policy for skill development and entrepreneurship 2015 for MAKE IN INDIA. The essence of this Endeavour is to create job opportunities and enhancing skill sets of the Indian workforce. The concept of MAKE IN INDIA is also working for raising quality standards on one hand and healthy and safe environment on the other. Indian workforce is the most hardworking and easily adaptable one. As we know workforce of India is the second largest in the world after China. So we have an abundance of human resource in our country. Now, due to rapid advancement in technologies the working style and organizational structure has also changed so to keep pace with such changes, it becomes imperative to train and to develop the workforce with an enhanced skill set likewise. Therefore we will have to make continuous efforts at a National and International level to maintain a free flow of demand and supply of human resource in the market. India is a developing nation, people of India are highly mobile, versatile and speak English fluently. As per the report of FICC, by the end of 2020, India will have 2 billion English speaking workforce and such a workforce will become a big player for the export in the service sector like BPOs, KPOs etc. along with the exporter of manpower itself. The $11^{\text {th }}$ five yrs. plan established 3- tier institutional structure having Prime Ministers National Council, National skill development coordination board and National skill Development Corporation which were created to ripe the benefit of skilling 500 million people by 2022. Although employment generation is taking place in service industries still there is a need to develop a skill set for employing the population of India in activities like agriculture, food processing , leather products, textiles, trade restaurants and hotels , tourism, construction and IT as well as for small and medium enterprises too. The support of the Govt. In collaboration with foreign countries helps in the development, execution, implementation, evaluation , and controlling of skill development programmes in India. The knowledge (implicit and explicit) gained through training and development programmes helps in sharing success and failure experiences of the employees and this in turns help in achieving the aim of skill development through training and development programmes. The nation which lacks skilled workforce may face issues relating to productivity , R\&D , unemployment etc. which reduces their share in international as well as the national market. So to win the race and to be ahead of all other nations. India needs to gear up the speed of skilling its human resource both at rural and urban levels of the country by focusing on the core as well as technical skill development.

\section{REFERENCES:}

1. Retrieved from http://planningcommission.gov.in

2. Skills for improved productivity, employment growth and development .(2008).Retrieved October 18, 2017, from http://www.ilo.org/wcmsp5/groups/public/-ed_norm/--

relconf/documents/meetingdocument/wcms_0920 54.pdf

3. Skills

Development

Sector

Profile.(2012).Retrieved October 15,2017, from http://www.ficciskillforum.org

4. National skill development policy report(2009) Retrieved October 9,2017, from http://www.skilldevelopment.gov.in/assets/images /NationalSkillDevelopmentPolicyMar09.pdf

5. A Skilled Workforce for Strong Sustainable and Balanced Growth .(2010).Retrieved November 18,2017,from htttp://www.ilo.org/wcmsp5/groups/public/--dgreports/-integration/documents/publication/wcms_151966. pdf 
6. http://Wikipedia.org

7. http://www.skilldevelopment.gov.in/

8. http://www.skilldevelopment.gov.in/NationalPolicy-2015.html

9. Retrieved from https://www.scribd.com/document/196214666/Kn
owledge-paper-on-Strategic-and-implementationframework-for-skill-development-in-IndiaSeptember-2011 